\title{
North American acetone sources determined from tall tower measurements and inverse modeling
}

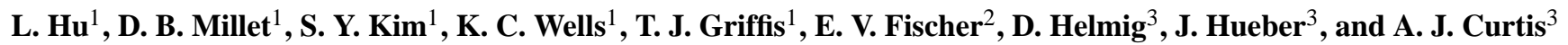 \\ ${ }^{1}$ Department of Soil, Water, and Climate, University of Minnesota, St. Paul, Minnesota, USA \\ ${ }^{2}$ School of Engineering and Applied Sciences, Harvard University, Cambridge, Massachusetts, USA \\ ${ }^{3}$ Institute of Arctic and Alpine Research, University of Colorado, Colorado, USA
}

Correspondence to: D. B. Millet (dbm@umn.edu)

Received: 20 November 2012 - Published in Atmos. Chem. Phys. Discuss.: 30 November 2012

Revised: 4 March 2013 - Accepted: 7 March 2013 - Published: 25 March 2013

\begin{abstract}
We apply a full year of continuous atmospheric acetone measurements from the University of Minnesota tall tower Trace Gas Observatory (KCMP tall tower; 244 m a.g.1.), with a $0.5^{\circ} \times 0.667^{\circ}$ GEOS-Chem nested grid simulation to develop quantitative new constraints on seasonal acetone sources over North America. Biogenic acetone emissions in the model are computed based on the MEGANv2.1 inventory. An inverse analysis of the tall tower observations implies a $37 \%$ underestimate of emissions from broadleaf trees, shrubs, and herbaceous plants, and an offsetting $40 \%$ overestimate of emissions from needleleaf trees plus secondary production from biogenic precursors. The overall result is a small (16\%) model underestimate of the total primary + secondary biogenic acetone source in North America. Our analysis shows that North American primary + secondary anthropogenic acetone sources in the model (based on the EPA NEI 2005 inventory) are accurate to within approximately $20 \%$. An optimized GEOSChem simulation incorporating the above findings captures $70 \%$ of the variance $(R=0.83)$ in the hourly measurements at the KCMP tall tower, with minimal bias. The resulting North American acetone source is $11 \mathrm{Tg} \mathrm{a}^{-1}$, including both primary emissions $\left(5.5 \mathrm{Tg} \mathrm{a}^{-1}\right)$ and secondary production $\left(5.5 \mathrm{Tg} \mathrm{a}^{-1}\right)$, and with roughly equal contributions from anthropogenic and biogenic sources. The North American acetone source alone is nearly as large as the total continental volatile organic compound (VOC) source from fossil fuel combustion. Using our optimized source estimates as a baseline, we evaluate the sensitivity of atmospheric acetone and peroxyacetyl nitrate (PAN) to shifts in natural and anthropogenic acetone sources over North America. Increased bio-
\end{abstract}

genic acetone emissions due to surface warming are likely to provide a significant offset to any future decrease in anthropogenic acetone emissions, particularly during summer.

\section{Introduction}

Acetone $\left(\mathrm{CH}_{3} \mathrm{C}(\mathrm{O}) \mathrm{CH}_{3}\right)$ is the simplest ketone and one of the most abundant volatile organic compounds (VOCs) in the atmosphere, with typical mixing ratios ranging from a few hundred parts per trillion (pptv) to several parts per billion (ppbv) or more (Chatfield et al., 1987; Singh et al., 1995; Arnold et al., 1997; Riemer et al., 1998; Goldstein and Schade, 2000; Karl et al., 2003; Lewis et al., 2005; Aiello and McLaren, 2009; Gao et al., 2013). It affects atmospheric chemistry as an important source of hydrogen oxide radicals $\left(\mathrm{HO}_{\mathrm{x}}=\mathrm{OH}+\mathrm{HO}_{2}\right)$ in the upper troposphere (Jaeglé et al., 1997, 2001; McKeen et al., 1997; Wennberg et al., 1998; Folkins and Chatfield, 2000; Arnold et al., 2005), and as a precursor of peroxyacetyl nitrate $\left(\mathrm{PAN}, \mathrm{CH}_{3} \mathrm{C}(\mathrm{O}) \mathrm{OONO}_{2}\right)$, which is a key reservoir for nitrogen oxides $\left(\mathrm{NO}_{\mathrm{x}}=\mathrm{NO}\right.$ $+\mathrm{NO}_{2}$ ) (Singh and Hanst, 1981; Singh et al., 1994, 1995; Arnold et al., 1997). Estimates of the global acetone source vary widely (40-200 Tg a ${ }^{-1}$; Singh et al., 2000; Potter et al., 2003; Singh et al., 2004; Arnold et al., 2005; Folberth et al., 2006; Elias et al., 2011; Fischer et al., 2012). Here we present a full year of continuous atmospheric acetone measurements from a tall tower observatory in the US Upper Midwest, and apply a nested chemical transport model (GEOS-Chem CTM) in an inverse analysis to develop quantitative new constraints on seasonal acetone sources over North America. 
Acetone is emitted by terrestrial vegetation as a by-product of plant metabolic processes, such as cyanogenesis and acetoacetate decarboxylation (Fall, 2003; Jardine et al., 2010), and during plant decay (de Gouw et al., 1999; Warneke et al., 1999). Recent estimates of the resulting biogenic flux to the atmosphere have ranged between 20 and $194 \mathrm{Tg} \mathrm{a}^{-1}$ (Singh et al., 2000, 2004; Jacob et al., 2002; Potter et al., 2003; Arnold et al., 2005; Lathière et al., 2006; Elias et al., 2011; Fischer et al., 2012; Guenther et al., 2012). The other principal source of atmospheric acetone is thought to be photochemical oxidation of precursor VOCs, including the predominantly anthropogenic 2-methyl alkanes (propane, isobutane, isopentane) as well as the biogenic 2-methyl-3-buten-2ol (MBO) and monoterpenes (Alvarado et al., 1999; Reissell et al., 1999). Other terrestrial sources include biomass burning (Simpson et al., 2011) and direct anthropogenic emissions (Goldan et al., 1995; Goldstein and Schade, 2000; de Gouw et al., 2005). Globally, the oceans appear to be both a gross source and a gross sink for atmospheric acetone (Fischer et al., 2012); however, the magnitude and variability of the corresponding net flux is quite uncertain (de Reus et al., 2003; Williams et al., 2004; Lewis et al., 2005; Marandino et al., 2005; Sinha et al., 2007; Taddei et al., 2009; Fischer et al., 2012; Read et al., 2012; Sjostedt et al., 2012). Along with gross oceanic uptake, sinks of atmospheric acetone include photochemical oxidation by $\mathrm{OH}$, photolysis, and deposition to land (Chatfield et al., 1987; McKeen et al., 1997; Gierczak et al., 1998; Blitz et al., 2004; Karl et al., 2010). The mean tropospheric lifetime of acetone is estimated to be between 14 and 35 days (Jacob et al., 2002; Arnold et al., 2005; Fischer et al., 2012).

The most recent laboratory study of the temperaturedependent quantum yields for acetone photolysis (Blitz et al., 2004) led to a significant change in our understanding of the atmospheric budget of acetone. Specifically, Blitz et al. (2004) measured the quantum yields to be substantially lower than previously reported. Those findings imply an increased acetone lifetime, and reverse the relative importance of photolysis and $\mathrm{OH}$ oxidation as acetone sinks (Fischer et al., 2012). They also modify the importance of acetone as a precursor of $\mathrm{HO}_{\mathrm{x}}$ and PAN (Arnold et al., 2005), leading to less PAN in the Northern Hemisphere (especially in the upper troposphere), but more PAN in parts of the Southern Hemisphere.

In this work, we employ the GEOS-Chem CTM and one year of continuous acetone measurements from the University of Minnesota tall tower Trace Gas Observatory (KCMP tall tower) in a Bayesian inverse framework to develop new top-down constraints on natural and anthropogenic acetone sources in North America. The tall tower measurements provide a high-resolution and long-term atmospheric dataset with a regional to continental-scale footprint that is influenced by a range of biogenic and anthropogenic sources (Hu et al., 2011). We then use these updated source estimates to investigate the impact of North American acetone sources on atmospheric PAN, and the sensitivity of atmospheric acetone and PAN to shifts in biogenic and anthropogenic acetone sources.

\section{Methods}

\subsection{Field site and PTR-MS measurements}

The University of Minnesota tall tower Trace Gas Observatory is a $244 \mathrm{~m}$ Minnesota Public Radio communications tower at Rosemount, MN (KCMP 89.3 FM, 44.689 $\mathrm{N}$, $93.073^{\circ} \mathrm{W}$; tower base is $290 \mathrm{~m}$ above sea level), located $28 \mathrm{~km}$ south of downtown St. Paul, MN, USA. A detailed description of the site is given elsewhere (Griffis et al., 2010; Hu et al., 2011).

Acetone (protonated $m / z$ 59) and a suite of other VOCs (including methanol, isoprene and its first-generation oxidation products, acetonitrile, and $\mathrm{C}_{6}-\mathrm{C}_{9}$ aromatics) were measured at the KCMP tall tower using a PTR-MS (proton transfer reaction mass spectrometer, Ionicon Analytic GmbH, Austria) between July 2009 and August 2012. The PTR-MS is housed in a climate-controlled communications building at the base of the tower. A continuous length of perfluoroalkoxy (PFA) sampling line $(0.95 \mathrm{~cm}$ ID $\times 1.27 \mathrm{~cm}$ OD, Jensen Inert Products, USA) is mounted on the tower, with an inlet and inline filter (90 mm PFA filter holder; 30-60 $\mu \mathrm{m}$ PTFE filter membrane, Savillex Corp., USA) installed at $185 \mathrm{~m}$ elevation. A sampling pump pulls air down from the inlet at $\sim 12$ standard liters per minute $\left(\mathrm{L} \mathrm{min}^{-1}\right)$, so that the residence time for air in the line is approximately 2 min under normal sampling conditions. A series of laboratory experiments showed no detectable effect from the long PFA inlet line on the measured acetone mixing ratios.

A detailed discussion of the measurement approach is provided by Hu et al. (2011). The PTR-MS is calibrated every $23 \mathrm{~h}$ (prior to August 2010) or $47 \mathrm{~h}$ (subsequently) by dynamic dilution of multi-component standards (Apel-Riemer Environmental Inc., USA) into a stream of catalytically generated zero air. The acetone standard was originally filled in December 2008 (nominal mixing ratio 152.6 ppbv, stated accuracy $\pm 5 \%$ ), and recertified in January 2012 (152.9 ppbv). Under most conditions, the $R^{2}$ values for 6-point calibration curves are $>0.99$ for acetone, with the relative standard deviation of residuals $<7 \%$. The detection limit, defined as $3 \times$ the measurement precision, is $\sim 30 \mathrm{pptv}$ for acetone (at $10 \mathrm{~s}$ dwell time). Typical sensitivity during calibration is 18 ncps ppbv ${ }^{-1}$ for a drift tube pressure of $2.2 \mathrm{mbar}$ and a drift tube voltage of $600 \mathrm{~V}$. The overall uncertainty of measurement for acetone, based on quadrature addition of the individual error sources (flow controllers, standard accuracy, calibration fit, standard error of the 30 min average, etc.), averages approximately $10 \%$ (and in nearly all cases is $<20 \%$ ). 


\subsection{GC-MS/FID measurements}

We also collected a series of cartridge samples at the tall tower to test the specificity of the PTR-MS measurements for acetone and other compounds. A total of 25 standard samples and 100 ambient samples were periodically collected between winter 2010 and summer 2012 for subsequent quantification by gas chromatography with mass selective and flame ionization detectors (GC-MS/FID) at the Institute of Arctic and Alpine Research, University of Colorado at Boulder.

Sample air was first scrubbed for ozone using sodiumthiosulfate coated glass fiber filters (Pollmann et al., 2005). The air was then dried to a dew point of $-25^{\circ} \mathrm{C}$ by flowing it through a Peltier-cooled stainless steel trap. Analytes were subsequently trapped on dual-bed adsorbent cartridges made of glass tubing $(0.64 \mathrm{~cm} \mathrm{OD} \times 9.00 \mathrm{~cm}$ length $)$ and filled with $0.15 \mathrm{mg}$ Carboxen 1016 and $0.15 \mathrm{mg}$ Carboxen 1000 solid adsorbents. The adsorbent tubes were cooled to $10^{\circ} \mathrm{C}$ during sampling using a custom-made autosampler similar to the one described in Helmig et al. (2004). Cartridges were stored in a freezer at $-18^{\circ} \mathrm{C}$ between sampling and analysis. A Perkin Elmer ATD-400 automated desorption unit was used for thermal desorption, with analytes then pre-focused on a dual-bed microtrap filled with Carboxen 1016 and Carboxen 1000 adsorbents. Gas chromatography separation was achieved on a $0.32 \mathrm{~mm}$ ID $\times 60 \mathrm{~m}$ length $\times 1.8 \mu \mathrm{m}$ film thickness DB-624 capillary column (Agilent, USA). The column flow was split for dual detection by electron impact mass spectrometry (Agilent MSD 5972, USA), in selected ion monitoring mode, and by flame ionization detection. Acetone was quantified from its $m / z=43$ and 58 mass fragment signals. Quantification was achieved after establishing response curves from analysis of a minimum of 5 calibration samples that were prepared by dynamic dilution of a $\sim 500$ ppbv standard (Apel-Riemer Environmental Inc., USA).

All standard intercomparisons between the UMN and CU cylinders agreed to within $10 \%$ for acetone, with no evidence of mixing ratio drift in the standard cylinders. Ambient intercomparisons $(n=85)$ between the PTR-MS and cartridge + GC-MS/FID systems showed good agreement for acetone: slope $=1.01$ (95\% confidence interval, CI: 0.92 $1.11)$, intercept $=-0.07 \mathrm{ppbv}(95 \% \mathrm{CI}:-0.21-0.05), R=$ 0.92. The fact that the slope and intercept are not significantly different from 1.0 and 0.0 , respectively, confirms that the PTR-MS acetone measurements (at $m / z$ 59) are robust, and that any interference (e.g., propanal) is minor, which is consistent with conclusions from previous studies (de Gouw et al, 2003; de Gouw and Warneke, 2007).

\subsection{GEOS-Chem chemical transport model}

We use the GEOS-Chem CTM version 9.1.3 to interpret the tall tower acetone observations. GEOS-Chem (http:// www.geos-chem.org) is a global Eulerian chemical transport model driven by NASA Goddard Earth Observing System
(GEOS-5.2.0) assimilated meteorological fields. In this work we employ a GEOS-Chem nested simulation (Wang et al., 2004; Chen et al., 2009; Zhang et al., 2009; van Donkelaar et al., 2012) over North America for 2010. The nested domain covers 10 to $70^{\circ} \mathrm{N}$ and 140 to $40^{\circ} \mathrm{W}$ (Fig. 1), with $0.5^{\circ} \times 0.667^{\circ}$ horizontal resolution and 47 model layers in the vertical extending up to $0.01 \mathrm{hPa}$ (14 layers are below $2 \mathrm{~km}$ altitude). Model transport occurs on a $10 \mathrm{~min}$ time step. Boundary layer mixing in GEOS-Chem uses the non-local scheme of Lin and McElroy (2010).

GEOS-Chem includes detailed $\mathrm{HO}_{\mathrm{x}}-\mathrm{NO}_{\mathrm{x}}$-VOC-ozone chemistry coupled to aerosols (Bey et al., 2001; Mao et al., 2010; Fischer et al., 2012). Photolysis frequencies are computed based on the Fast-JX scheme as implemented in GEOS-Chem by Mao et al. (2010), with updated quantum yields for acetone photodissociation from Blitz et al. (2004) and accounting for the effect of aerosol extinction on photolysis rates (Martin et al., 2003). A one year spin-up for 2009 is used to remove the effects of initial conditions. Lateral boundary conditions for all species at each vertical layer are based on 3-hourly output from year-long global simulations carried out at $4^{\circ} \times 5^{\circ}$ resolution (Wang et al., 2004; Chen et al., 2009; Zhang et al., 2009; van Donkelaar et al., 2012).

Biogenic emission of VOCs including acetone and its biogenic precursors (monoterpenes and $\mathrm{MBO}$ ) are computed online in GEOS-Chem using MEGANv2.1 (Model of Emissions of Gases and Aerosols from Nature; Guenther et al., 2012). Fluxes are calculated for each model grid square as a sum of contributions from four plant functional types (PFTs: broadleaf trees, needleleaf trees, shrubs, and herbaceous plants [crops + grasslands]):

$E=\gamma \sum_{i=1}^{4} \varepsilon_{i} \chi_{i}$,

where $\varepsilon_{i}$ is the canopy emission factor for PFT $i$ with fractional coverage $\chi_{i}$. The canopy emission factors $(\varepsilon)$ for acetone are $240 \mu \mathrm{g} \mathrm{m}^{-2} \mathrm{~h}^{-1}$ for broadleaf trees, needleleaf trees, and shrubs, and $80 \mu \mathrm{g} \mathrm{m}^{-2} \mathrm{~h}^{-1}$ for herbaceous plants (Guenther et al., 2012). The non-dimensional activity factor $\gamma$ scales the emissions according to local environmental conditions (leaf age, surface temperature, light, leaf area index) according to Guenther et al. (2012), assuming a light-dependent fraction of 0.2 for acetone emissions (i.e., $20 \%$ of the emissions are influenced by light). The temperature dependence of acetone emissions is simulated using an exponential $\beta$ coefficient of 0.10 . The MEGANv2.1 acetone emission factors and light and temperature dependencies have been established based on a limited set of enclosure and above canopy eddy flux measurements (e.g., Macdonald and Fall, 1993b; Janson et al., 1999; Baker et al., 2001; Schade and Goldstein, 2001; Karl et al., 2002, 2004), and are highly uncertain. Part of our objective here is to apply the KCMP tall tower data to evaluate and better constrain the simulated biogenic acetone flux. 

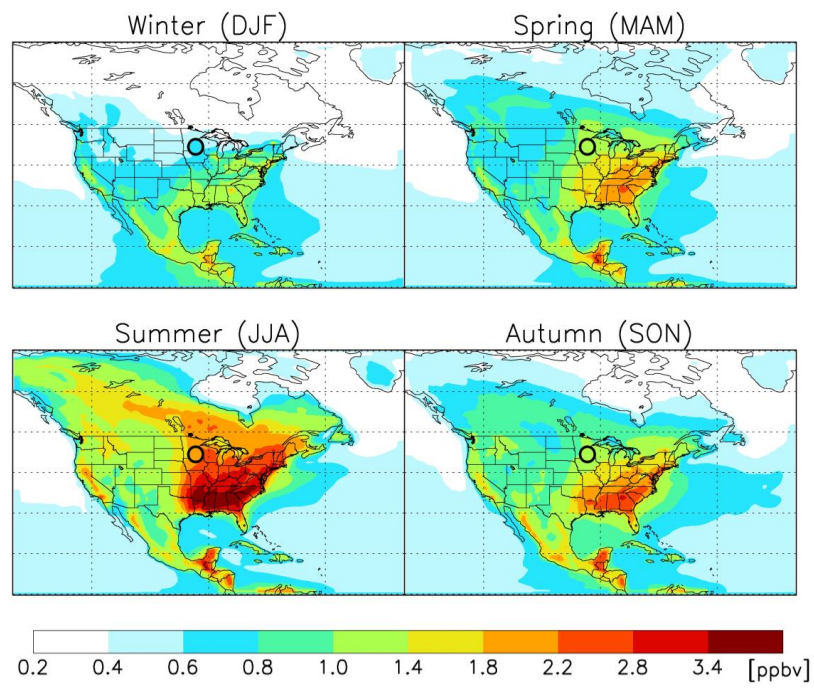

Fig. 1. Surface acetone mixing ratios over the nested North American domain $\left(10-70^{\circ} \mathrm{N} ; 140-40^{\circ} \mathrm{W}\right)$ in the GEOS-Chem a priori simulation for the year 2010 . A sub-domain $\left(13-70^{\circ} \mathrm{N} ; 140\right.$ $50^{\circ} \mathrm{W}$ ) is used in the paper for computing North American source magnitudes. Measured mixing ratios at the KCMP tall tower $\left(44.689^{\circ} \mathrm{N}, 93.073^{\circ} \mathrm{W}\right)$ are indicated by the filled circle on the same color scale.

Photochemical acetone production from oxidation of biogenic monoterpenes and $\mathrm{MBO}$ is computed based on MEGANv2.1 emissions of those species (Guenther et al., 2012) and fixed average molar acetone yields ( 0.12 for monoterpenes, 0.60 for MBO), following earlier work (Jacob et al., 2002; Fischer et al., 2012). The resulting a priori terrestrial North American biogenic acetone source over the domain of Fig. 1 is $4.8 \mathrm{Tg}$ in 2010 (76\% primary, $24 \%$ secondary), which is approximately $13 \%$ of the global terrestrial biogenic acetone source (Fischer et al., 2012).

Direct anthropogenic emissions of acetone and its alkane precursors over North America are derived from the US EPA National Emission Inventory for 2005, NEI 2005 (EPA, 2005). The total a priori North American anthropogenic acetone source in the model is then $4.9 \mathrm{Tg} \mathrm{a}^{-1}(12 \%$ primary, $88 \%$ secondary) within the domain of Fig. 1. The total anthropogenic acetone source is thus similar to the total biogenic source over the region, and accounts for approximately $19 \%$ of the global anthropogenic acetone source for 2010 . Biomass burning emissions of acetone and isoalkanes are computed based on the monthly GFED3 inventory (Global Fire Emissions Database version 3) (van der Werf et al., 2010) and measured species : species pyrogenic emission ratios (Andreae and Merlet, 2001), giving a total North American acetone source from fires of $0.1 \mathrm{Tg}$ for 2010 .

Acetone sinks (including oxidization by $\mathrm{OH}$, photolysis, and deposition) and bidirectional oceanic exchange are computed following Fischer et al. (2012). We use a rate constant $k=3.28 \times 10^{-11} \exp [-200 / T]$ for the oxidation of acetone by $\mathrm{OH}$ (Sander et al., 2011) and absorption cross sections and photolysis quantum yields from Blitz et al. (2004). Dry deposition is computed assuming a constant deposition velocity of $0.1 \mathrm{~cm} \mathrm{~s}^{-1}$ for ice-free land (Jacob et al., 2002; Fischer et al., 2012).

\section{Results and analysis}

\subsection{Acetone abundance in the US Upper Midwest and its relationship with methanol}

Figure 2 shows hourly mean acetone mixing ratios measured from January 2010 through February 2011 at the KCMP tall tower. Statistical outliers ( $>0.98$ quantile for each month) have been removed prior to plotting. We also show in Fig. 2 concurrent measurements of methanol. Hu et al. (2011) showed that atmospheric methanol in this region is predominately (nearly $90 \%$ ) biogenic during summer, with a mixture of contributing sources (including $40 \%$ from anthropogenic emissions) during winter.

The 2010 annual mean acetone mixing ratio at the KCMP tall tower is $1.2 \mathrm{ppbv}$ (median $1.0 \mathrm{ppbv}$ ), with strong seasonal changes. As with methanol, the lowest observed acetone mixing ratios occur during winter, with a DecemberFebruary mean of $0.6 \mathrm{ppbv}$ (Table 1). Mixing ratios are highest during summer, driven by biogenic emissions and enhanced photochemical production at that time of year (JuneAugust mean $2.1 \mathrm{ppbv}$; Table 1). However, while methanol mixing ratios peak during early summer (mid-July), the seasonal peak for acetone occurs later in the season (midAugust). This seasonal offset arises from the differing source characteristics for the two compounds. Methanol is thought to be produced in plants mainly as a by-product of pectin demethylation during plant and leaf growth, leading to peak mixing ratios early in the growing season (MacDonald and Fall, 1993a; Fall and Benson, 1996; Hu et al., 2011; Wells et al., 2012). While biogenic emissions of acetone clearly drive the observed seasonality for this compound as well (as shown later in Sect. 3.5), these emissions are thought to be related to a number of different biological pathways (Macdonald and Fall, 1993b; Fall, 2003; Jardine et al., 2010), and no clear dependence on leaf age has been observed (Karl et al., 2003). Unlike methanol, which has a diffuse secondary source mainly from the oxidation of methane (Jacob et al., 2005; Millet et al., 2008), acetone also has a strong photochemical source from biogenic and anthropogenic precursor VOCs (Goldstein and Schade, 2000; de Gouw et al., 2005).

Based on the acetone: methanol correlation $(R=0.83$, $n=6637$ for year-2010), and the fact that methanol is mainly biogenic during summer, we initially tried to estimate the importance of biogenic acetone sources at the KCMP tall tower using methanol as a biogenic tracer. However, the distinct seasonal trajectories for the two compounds complicate such an analysis. We see in Fig. 3 that the differing source 
Table 1. Seasonal acetone mixing ratios measured at the KCMP tall tower.

\begin{tabular}{|c|c|c|}
\hline & Statistic & Value (ppbv) \\
\hline \multirow[t]{2}{*}{ Spring $^{1}$} & mean & 1.3 \\
\hline & median (10th-90th percentiles) & $1.2(0.7-2.0)$ \\
\hline \multirow[t]{2}{*}{ Summer $^{2}$} & mean & 2.1 \\
\hline & median (10th-90th percentiles) & $2.1(1.4-2.8)$ \\
\hline \multirow[t]{2}{*}{ Autumn ${ }^{3}$} & mean & 1.1 \\
\hline & median (10th-90th percentiles) & $1.0(0.5-1.9)$ \\
\hline \multirow[t]{2}{*}{ Winter ${ }^{4}$} & mean & 0.6 \\
\hline & median (10th-90th percentiles) & $0.6(0.4-0.9)$ \\
\hline
\end{tabular}

${ }^{1}$ Spring: March-May; ${ }^{2}$ Summer: June-August; ${ }^{3}$ Autumn:

September-November; ${ }^{4}$ Winter: December-February.

characteristics drive seasonal shifts in the strength of the acetone : methanol correlation, with the highest correlation occurring during spring and autumn, and the lowest during winter and summer. Also, the measured acetone vs. methanol regression slopes are relatively consistent year-round at the KCMP tall tower (0.20-0.31; mean 0.25), suggesting that, while in the annual sum methanol sources are mainly natural, the effective acetone: methanol ratios for biogenic and anthropogenic sources are quite similar. This makes it difficult to effectively segregate acetone sources based on this correlation. During winter, biogenic emissions are negligible for both compounds, and the slope at this time can be interpreted as the mean anthropogenic acetone : methanol emission ratio (95\% CI: 0.19-0.23; Fig. 3). This is nearly identical to the slope during summer (95\% CI: 0.19-0.22; Fig. 3), when biogenic emissions are the predominant source of methanol $(\mathrm{Hu}$ et al., 2011) and account for approximately half the acetone abundance (as shown later).

\subsection{Inverse analysis}

In this section, we use a Bayesian optimization approach to interpret the KCMP tall tower observations in terms of the information they provide on North American acetone sources. The method derives the optimal set of acetone sources most consistent with observational constraints (i.e., the tall tower acetone measurements) and with prior knowledge (i.e., the a priori primary and secondary sources described in Sect. 2.3) by minimizing the cost function $J(\boldsymbol{x})$ (Rodgers, 2000):

$J(x)=\left(\boldsymbol{x}-\boldsymbol{x}_{\mathrm{a}}\right)^{T} \mathbf{S}_{\mathrm{a}}^{-1}\left(\boldsymbol{x}-\boldsymbol{x}_{\mathrm{a}}\right)+(\mathbf{K} \boldsymbol{x}-\boldsymbol{y})^{T} \mathbf{S}_{\Sigma}^{-1}(\mathbf{K} \boldsymbol{x}-\boldsymbol{y})$,

The first term on the right hand side of the equation represents the error-weighted misfit between the sources being optimized $(\boldsymbol{x})$ and their initial guess values $\left(\boldsymbol{x}_{\mathrm{a}}\right)$, while the second term represents the error-weighted misfit between the predicted $(\mathbf{K} \boldsymbol{x})$ and observed $(\boldsymbol{y})$ acetone mixing ratios. $\mathbf{S}_{\mathrm{a}}$ and $\mathbf{S}_{\Sigma}$ are the a priori and observational error covariance matrices, respectively (Heald et al., 2004).
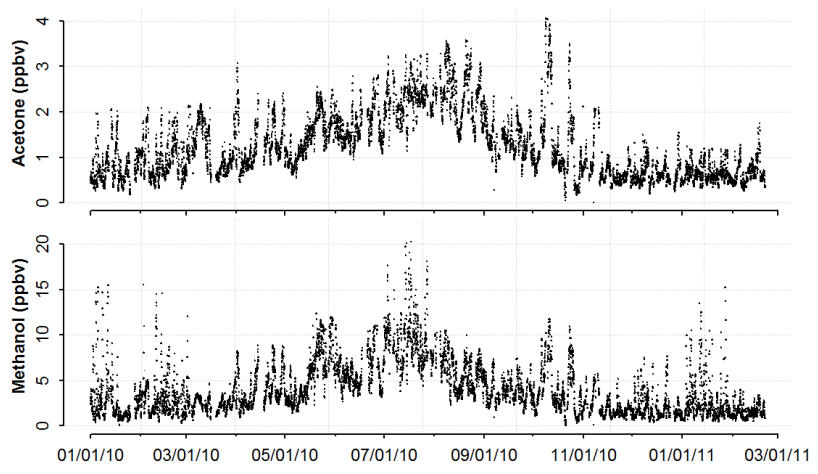

Fig. 2. Annual cycle in atmospheric acetone and methanol observed at the KCMP tall tower from January 2010 through February 2011. All data points are $1 \mathrm{~h}$ averages. Statistical outliers $(>0.98$ quantile for each month) have been removed prior to plotting.

We construct the Jacobian matrix $\mathbf{K}$ by perturbing each model source individually (excluding gross ocean emissions) by $10 \%$, rerunning the model, and calculating the resulting change in acetone mixing ratios at the KCMP tall tower. These sensitivities were derived with respect to eight distinct acetone sources within the North American domain of Fig. 1: biogenic emissions from broadleaf trees, needleleaf trees, shrubs, and herbaceous plants; secondary production from biogenic precursors; primary anthropogenic emissions; secondary production from anthropogenic precursors; and biomass burning. We also derive the sensitivity with respect to sources outside North America, manifested as the boundary conditions for the nested model domain. We verified the assumption of a linear relationship between acetone sources and mixing ratios by comparing the scaled sum of all sensitivities from the perturbed simulations to the baseline total acetone mixing ratios simulated at the KCMP tall tower $(R=1.00$, slope $=1.00, n=8737)$.

We estimate the errors in the prior source terms at $100 \%$, and assume they are uncorrelated, so that the resulting a priori error covariance matrix $\mathbf{S}_{\mathrm{a}}$ is diagonal. The observational error covariance matrix $\mathbf{S}_{\Sigma}$ is constructed by combining the measurement error $\left(\mathbf{S}_{\text {meas }}\right)$ and the model error $\left(\mathbf{S}_{\text {mod }}\right)$, assuming they are uncorrelated so that $\mathbf{S}_{\Sigma}$ is also diagonal. We estimate the measurement uncertainty at $30 \mathrm{pptv}+10 \%$ (Sect. 2). The forward model uncertainty includes representation error, transport error, and any error due to other model processes that are not included in the state vector $\boldsymbol{x}$ being optimized (Palmer et al., 2003; Heald et al., 2004). Representation error, describing the mismatch between model and observations due to subgrid-scale variability (Palmer et al., 2003), can be assumed to be negligible for this analysis due to the large footprint of the KCMP tall tower (sampling height at $185 \mathrm{~m}$ a.g.1.) combined with the high resolution of the nested model simulation $\left(0.5^{\circ} \times 0.667^{\circ}\right)$. A dominant contributor to model transport uncertainty is the simulated boundary layer depth. Here we assess that error by 

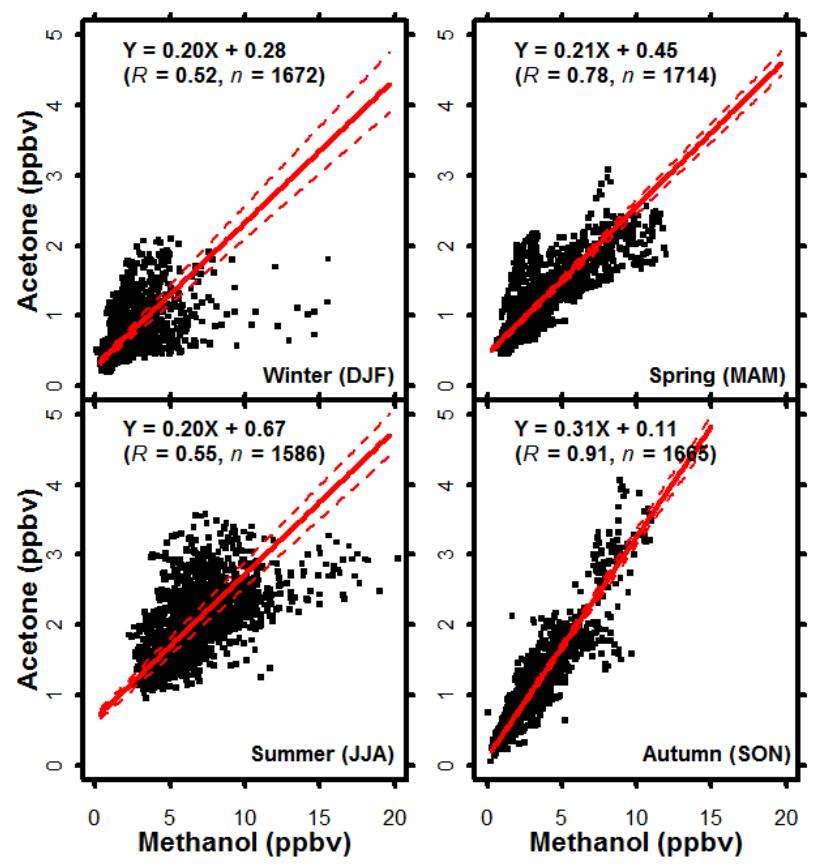

Fig. 3. Seasonal linear correlation (major axis regression) between atmospheric acetone and methanol mixing ratios observed at the KCMP tall tower in 2010. Red dashed lines show the $95 \%$ confidence interval for the best fit line (red solid line). Data points are $1 \mathrm{~h}$ means.

comparing the GEOS-5.2.0 mixing depths at the KCMP tall tower with nearby radiosonde data (NOAA NCDC Station Minneapolis, ID $72649,44.85^{\circ} \mathrm{N}, 93.57^{\circ} \mathrm{W}$, approximately $40 \mathrm{~km}$ northwest of the KCMP tall tower). We find that the GEOS mixing depths in 2010 are generally consistent with the observations to better than $20 \%$ (slope $=0.90, R=0.78$, $n=353$ ). We thus employ a forward model uncertainty of $20 \%$. Later, we examine the degree to which our inversion results depend on the above assumptions used to construct $\mathbf{S}_{\mathrm{a}}$ and $\mathbf{S}_{\Sigma}$.

Our initial analyses employed the above ensemble of nine source types as state vector for the inverse calculation. We find, however, that biomass burning has only a minor impact on simulated acetone mixing ratios at the KCMP tall tower (up to $8 \%$ for specific events in spring, but $<1 \%$ for the rest of 2010), so we do not attempt to constrain that source. We also merge needleleaf tree emissions and secondary biogenic production into a single acetone source category in the following analysis, since the two are highly correlated in the model $(R=0.97, n=6637)$. We then performed a series of tests to examine how well the remaining seven source types can be resolved based on the KCMP tall tower observations. First, we inspected the averaging kernel matrix and the singular value of the prewhitened Jacobian for the system (Palmer et al., 2003; Heald et al., 2004). However, we found that both methods provided an overly optimistic measure of the re- solving power of the KCMP dataset, based on the fact that the resulting state vector combinations led to unrealistic and non-physical solutions.

We instead employ a pseudo-observation analysis to aid in identifying an appropriate combination of elements to include in the state vector. A synthetic dataset was created by reducing all model acetone sources by $50 \%$, with random measurement and model noise then applied to the simulated mixing ratios (normally distributed with zero mean and standard deviation equal to $21 \%$ of the simulated value). We then tested different state vector combinations in the inverse analysis in terms of their ability to return a posteriori scale factors approaching the true value of 0.5 . In this way, we selected a four-element state vector, composed of (1) acetone emissions from broadleaf trees, shrubs, and herbaceous plants $(\mathrm{BT}+\mathrm{SH}+\mathrm{HB}),(2)$ emissions from needleleaf trees plus secondary production from biogenic precursors (NT+BIOG2), (3) primary and secondary anthropogenic acetone sources (ANTH), and (4) sources outside North America/long-range transport (BOUNDARY). The corresponding scale factors in the pseudo-observations test for those source combinations were $0.54,0.57,0.50$, and 0.37 , respectively. Based on this analysis, we can expect inversion of the KCMP observations to resolve these North American source categories to better than $20 \%$, with a slightly higher error for the boundary condition.

\subsection{Optimized North American acetone sources}

Figure 4 shows the a posteriori scale factors for our four North American acetone source categories: acetone emissions from broadleaf trees + shrubs + herbaceous plants $(\mathrm{BT}+\mathrm{SH}+\mathrm{HB})$, emissions from needleleaf trees + secondary production from biogenic precursors $(\mathrm{NT}+\mathrm{BIOG} 2)$, primary + secondary anthropogenic acetone sources (ANTH), and long-range transport associated with sources outside North America (BOUNDARY). The results imply a $37 \%$ model underestimate (a posteriori scale factor, $\mathrm{SF}=1.37 ; 95 \% \mathrm{CI}=1.22-1.52)$ of acetone emissions from broadleaf trees, shrubs, and herbaceous plants, and a $40 \%$ overestimate ( $\mathrm{SF}=0.60 ; 95 \% \mathrm{CI}=0.45-0.79)$ of emissions from needleleaf trees plus secondary production from biogenic precursors. Confidence intervals are derived as described later in Sect. 3.4. Overall, this corresponds to a $16 \%$ underestimate of the total North American biogenic acetone source (including primary and secondary contributions) in the a priori model.

These opposing changes to the prior source estimates for the broadleaf tree + shrub + herbaceous plant category and the needleleaf tree + secondary biogenic production category probably reflect a misrepresentation of the associated canopy emission factors in MEGAN. Errors in land cover or in the MEGAN activity factors that scale emissions according to environmental conditions could also be responsible. However, Guenther et al. (2012) found that specification 


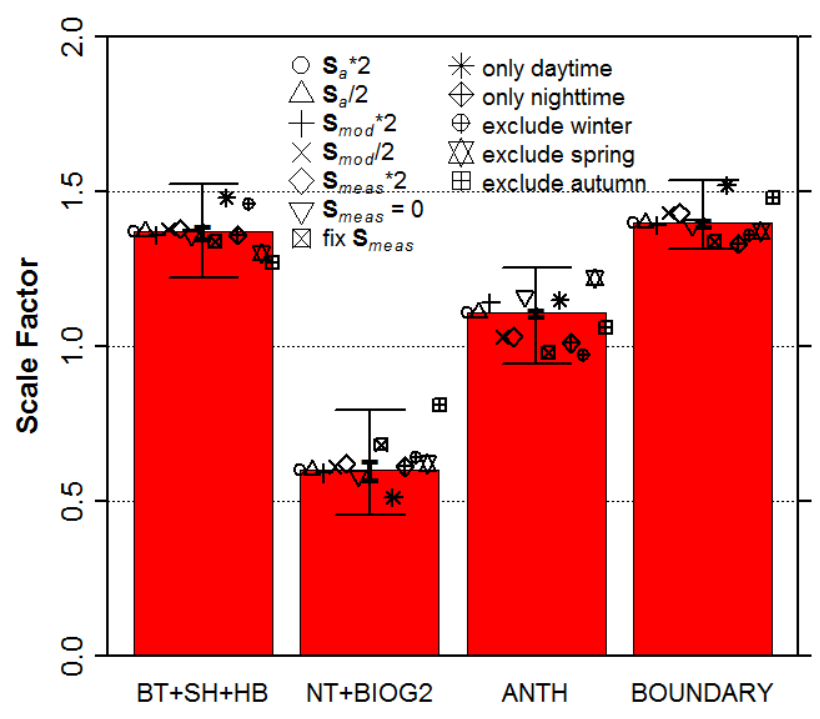

Fig. 4. A posteriori scale factors for North American acetone sources computed on the basis of the KCMP tall tower measurements: $\mathrm{BT}+\mathrm{SH}+\mathrm{HB}$, broadleaf trees + shrubs + herbaceous plants; NT+BIOG2, needleleaf trees + photochemical production from biogenic precursors; ANTH, primary + secondary anthropogenic sources; BOUNDARY, acetone boundary condition/longrange transport. Also shown is the range of scale factors derived from an ensemble of sensitivity calculations (see text). Thin error bars show $95 \%$ confidence intervals derived from a bootstrap analysis as described in the text. Thick error bars show the a posteriori errors from the inversion analysis. A priori scale factors are one in all cases.

of emission factors for various land cover types represents the largest contributor to the overall emission estimate uncertainty for biogenic VOCs.

Another possible explanation would be errors in the meteorological fields used to drive GEOS-Chem and MEGAN, but this appears less likely. In our previous work we found that the GEOS-5 surface air temperatures agree well with the observed values at KCMP tall tower (average bias $-0.9^{\circ} \mathrm{C}$, $\mathrm{Hu}$ et al., 2011). Likewise, the simulated mixing depths appear consistent with radiosonde observations (Sect. 3.2). In addition, any model bias in temperature, light, or other environmental parameter would likely affect biogenic emissions from all plant types in the same direction (unless the bias happened to be correlated with the PFT distributions), whereas we find an increase for one source category versus a decrease for the other. However, because of the way source categories are combined in the state vector, we cannot rule out the possibility of an underestimate of direct acetone emission across all PFTs, combined with an overestimate of secondary biogenic production.
We find that the simulated North American anthropogenic acetone source (computed based on EPA's NEI 2005) is accurate to within the constraints provided by the KCMP tall tower observations ( $\mathrm{SF}=1.11 ; 95 \% \mathrm{CI}=0.94-1.26)$. The optimization is not capable of resolving the relative importance of primary versus secondary anthropogenic sources of atmospheric acetone, as these are highly correlated (model $R=0.68$ at the KCMP tall tower). However, as we show later (Sect. 3.5), the secondary anthropogenic acetone source in the model predominates over primary emissions, so that the a posteriori scale factor for the total anthropogenic source is mainly weighted towards this secondary fraction.

We also infer a $40 \%$ underestimate $(\mathrm{SF}=1.40 ; 95 \% \mathrm{CI}=$ 1.31-1.54) of the acetone boundary condition for our North American domain (Fig. 1). This could be due to a number of upstream acetone source or sink processes, including an underestimate of emissions elsewhere in the world, a misdiagnosis of the air-ocean flux, or an underestimate of the acetone lifetime. However, given the atmospheric lifetime for acetone (32 days against photochemical loss and land uptake; Fischer et al., 2012), we do not expect our derived constraints on North American sources to be particularly sensitive to uncertainty in model $\mathrm{OH}$ or deposition; any such error would mainly manifest as a problem with the boundary conditions and be corrected by the corresponding scale factor.

Figure 5 shows that the resulting optimized simulation captures $70 \%$ of the variance in the 2010 hourly measurements at the KCMP tall tower, with minimal bias $(R=0.83$, slope $=1.03)$. Model $:$ measurement slopes for individual seasons are all within $20 \%$ of unity. However, the winter comparison reveals two populations (red dots in Fig. 5), with most of the simulated values lower than the observations. This bifurcation is due to the fact that our sampling height $(185 \mathrm{~m})$ is close to the mixing depth in winter. At times, the GEOS mixing depths are slightly lower than our sampling height while the actual mixing depths are above it, so that the model is sampling the free troposphere while the actual measurements are within the boundary layer. We examine this point in more detail later to see how it affects our inversion results (Sect. 3.4; Fig. 4).

We thus estimate the total acetone source from North America at $10.9 \mathrm{Tg}$ for 2010 (excluding gross oceanic emission; Table 2), which is consistent with the a priori model source $(9.7 \mathrm{Tg})$ to within uncertainty. Including both primary (3.0 TgC biogenic; $0.4 \mathrm{TgC}$ anthropogenic) and secondary ( $0.4 \mathrm{TgC}$ biogenic; $3.0 \mathrm{TgC}$ anthropogenic) contributions, the continental acetone source is then nearly as large as the sum of all direct fossil fuel VOC emissions from North America (6.8 $\mathrm{TgC}$ versus $9.2 \mathrm{TgC})$. Annually, we find that direct biogenic emissions (44\%) and secondary production from anthropogenic precursors (44\%) are the predominant North American acetone sources in the optimized simulation, followed by secondary production from biogenic precursors $(6 \%)$, primary anthropogenic emissions $(6 \%)$, and a minor biomass burning source $(<1 \%)$. 
Table 2. North American ${ }^{1}$ acetone sources $\left(\mathrm{Tg} \mathrm{a}^{-1}\right)$ : A priori forward model sources and a posteriori sources optimized based on the KCMP tall tower measurements. $95 \%$ confidence intervals for the optimized posteriori sources are provided in parentheses.

\begin{tabular}{llllll}
\hline & Biogenic $^{2}$ & Anthropogenic $^{2}$ & $\begin{array}{l}\text { Biomass } \\
\text { burning }\end{array}$ & NA Total & \\
\hline A priori & 4.8 & 4.9 & 0.06 & $\begin{array}{l}\text { Cost Function } \\
\text { Reduction }\end{array}$ \\
A posteriori & $5.5(4.7-6.5)$ & $5.4(4.5-6.0)$ & 0.06 & $10.9(9.2-12.5)$ & 1.37 \\
\hline
\end{tabular}

${ }^{1}$ North America is defined here as the domain from 13 to $70^{\circ} \mathrm{N}$ and 140 to $50^{\circ} \mathrm{W} .{ }^{2}$ Including both primary emissions and secondary photochemical production. ${ }^{3}$ Total North American acetone source, excluding ocean exchange. ${ }^{4} J_{\text {initial }} / J_{\text {final }}$.

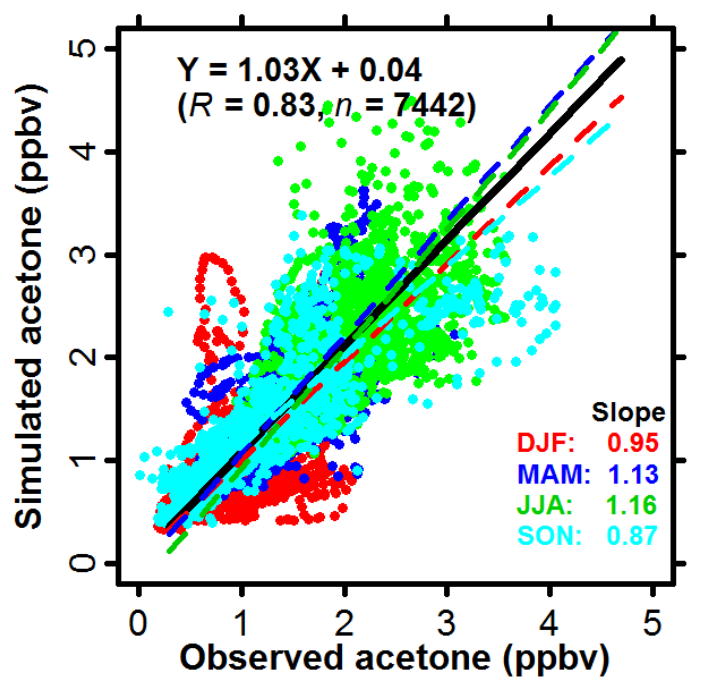

Fig. 5. Atmospheric acetone mixing ratios from the optimized GEOS-Chem simulation compared to observations at the KCMP tall tower in 2010, colored by season. Data points are $1 \mathrm{~h}$ mean values.

\subsection{Uncertainty analysis}

We carried out a series of sensitivity tests to quantify the uncertainty in our acetone source estimates. These included various modifications to the error covariance matrices $\mathbf{S}_{\mathrm{a}}$ and $\mathbf{S}_{\Sigma}$ (halving and doubling $\mathbf{S}_{\mathrm{a}}, \mathbf{S}_{\text {mod }}$, and $\mathbf{S}_{\text {meas }}$; setting $\mathbf{S}_{\text {meas }}$ to a fixed value of $10 \%$ or 0 ), along with a series of test inversions designed to assess the impact of model transport uncertainty (using only daytime data; only nighttime data; and excluding each season). Finally, we applied a bootstrap analysis to resample ( $>1000$ times) our hourly observations for each of the above sensitivity analyses in order to obtain confidence intervals for the resulting a posteriori scale factors. The final uncertainties for the a posteriori estimates are taken as the 5$95 \%$ probability range across all sensitivity inversions, and are shown in Fig. 4.

\subsection{Source apportionment for acetone in the US Upper Midwest}

Our optimized (a posteriori) acetone simulation is able to capture much of the observed variability in acetone mixing ratios at the KCMP tall tower throughout the year, and we therefore apply it to interpret the tall tower observations in terms of the seasonal importance of different acetone sources for this region.

On a yearly basis, North American biogenic sources, North American anthropogenic sources, and long-range transport (i.e., from outside the North American domain of Fig. 1) make similar contributions to acetone levels in the US Upper Midwest (32\%, 32\%, 36\%, respectively), though with differing seasonality. Figure 6 (top panel) shows that the weekly mean acetone contribution from long-range transport is approximately $0.5 \mathrm{ppbv}$ year-round, with no major seasonal variation. North American anthropogenic sources, predominantly secondary in origin, are of comparable importance in the annual mean $(0.4 \mathrm{ppbv})$, but with episodic enhancements during winter and spring. The relatively weak seasonality seen for the secondary anthropogenic and longrange transport contributions likely reflects a compensation between an increased photochemical production rate in the summer and a longer acetone lifetime in the winter.

The bottom panel of Fig. 6 shows that, during winter, acetone in the US Upper Midwest arises mainly from sources outside North America $(50 \%)$ and from anthropogenic sources within North America (45\%). Biogenic sources become important starting in April, and exceed the sum of anthropogenic sources plus long-range transport from May through the middle of September. During summer, North American anthropogenic sources $(20 \%)$ and longrange transport (19\%) play relatively modest roles; biogenic sources predominate (47\% primary; $14 \%$ secondary; Fig. 6). Among biogenic sources, crop and grassland emissions are most important, accounting for a third of the total biogenic acetone at the KCMP tall tower during the growing season, followed by secondary biogenic production $(24 \%)$, emissions from needleleaf trees $(16 \%)$, broadleaf trees $(14 \%)$, and shrubs (13\%). As we see in Fig. 6, the strong observed seasonality in atmospheric acetone is mainly driven by the changing importance of biogenic emissions. 


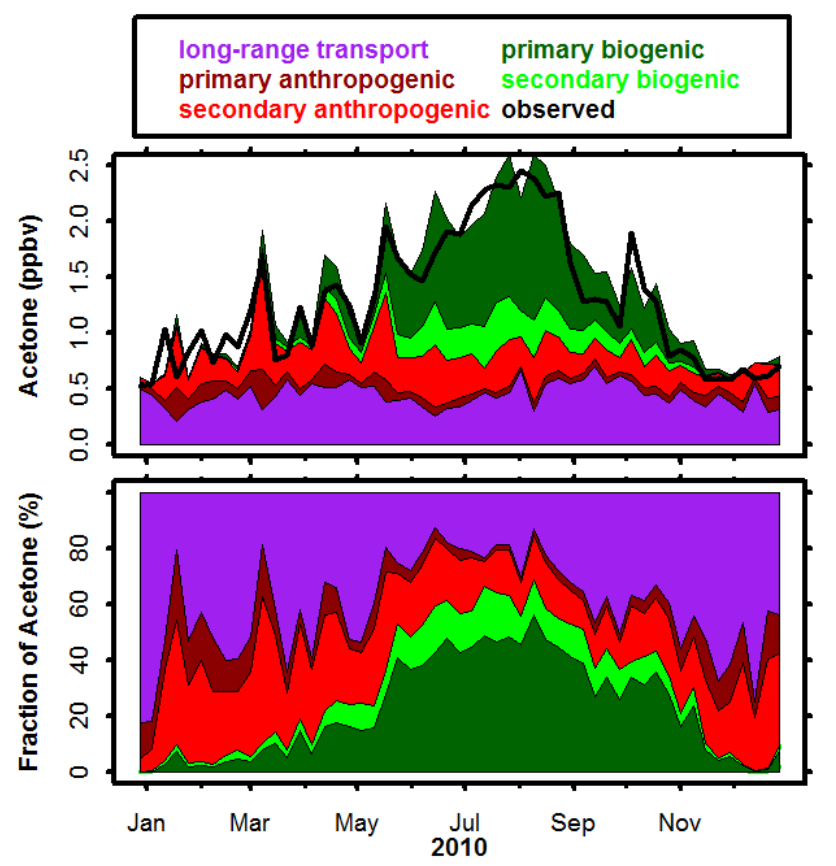

Fig. 6. Top panel: stack plot of the seasonal acetone mixing ratios from various sources in the optimized GEOS-Chem simulation at the KCMP tall tower. Also shown are the observed acetone mixing ratios at the tall tower (black line). Bottom panel: fractional contribution of these sources to the total modeled acetone abundance in the optimized simulation.

\subsection{Sensitivity of acetone and PAN to shifts in North American acetone sources}

Acetone photolysis is a significant source of PAN, especially in the mid- and upper troposphere (Singh et al., 1994):

$$
\begin{aligned}
& \mathrm{CH}_{3} \mathrm{C}(\mathrm{O}) \mathrm{CH}_{3}+h v+2 \mathrm{O}_{2} \rightarrow \mathrm{CH}_{3} \mathrm{C}(\mathrm{O}) \mathrm{O}_{2}+\mathrm{CH}_{3} \mathrm{O}_{2} \\
& \mathrm{CH}_{3} \mathrm{C}(\mathrm{O}) \mathrm{O}_{2}+\mathrm{NO}_{2}+\mathrm{M} \rightleftharpoons \mathrm{CH}_{3} \mathrm{C}(\mathrm{O}) \mathrm{O}_{2} \mathrm{NO}_{2}+\mathrm{M} .
\end{aligned}
$$

Acetone sources thus affect the partitioning and long-range transport of atmospheric reactive nitrogen. However, the updated quantum yields for acetone photodissociation lead to lower predicted photolysis rates throughout the troposphere, and especially in the cold upper troposphere (Blitz et al., 2004; Arnold et al., 2005). In this section, we examine the sensitivity of atmospheric PAN to changes in North American acetone sources, using our optimized acetone budget as a baseline.

To assess this sensitivity, we carry out a perturbation analysis in which North American (primary + secondary) acetone biogenic sources are increased by $35 \%(+35 \%$ BIOG). This is similar, for example, to the acetone emission increase expected for a $3{ }^{\circ} \mathrm{C}$ surface warming based on the MEGANv2.1 temperature dependence of emissions ( $\beta=0.10$; Guenther et al., 2012). We also carry out a second perturbation analysis in which anthropogenic acetone

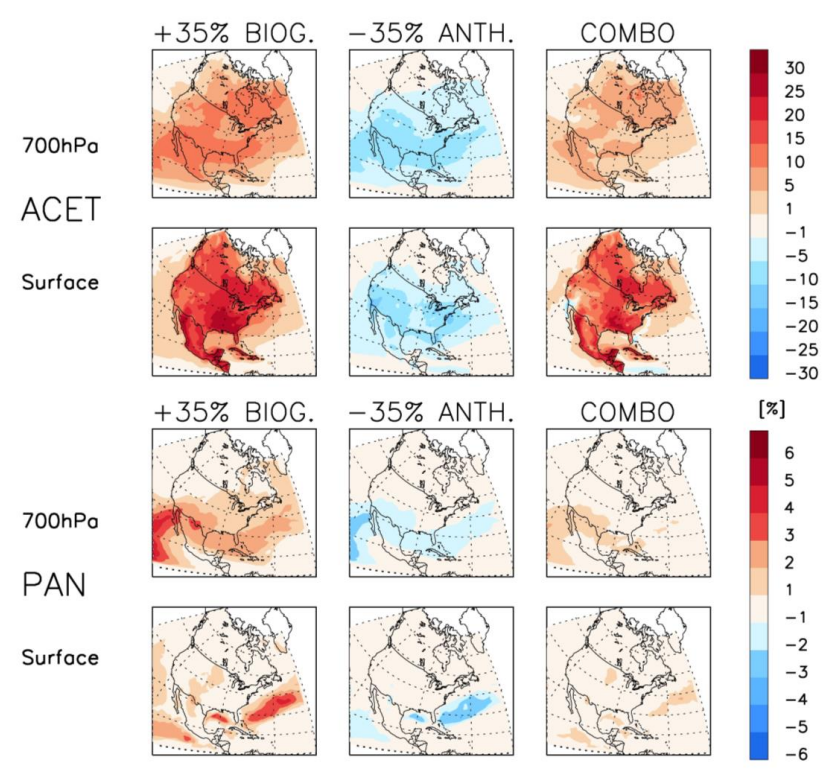

Fig. 7. Sensitivity of atmospheric acetone and PAN to biogenic and anthropogenic source changes in North America during August. Shown are the percent changes due to a $35 \%$ increase in primary + secondary biogenic acetone sources $(+35 \%$ BIOG), a $35 \%$ decrease in primary + secondary anthropogenic sources $(-35 \%$ ANTH), and the combined effect of the two (COMBO). Note differing color bars for acetone and PAN.

sources from North America are reduced by the same fraction $(-35 \%$ ANTH; again including both primary and secondary components). A final sensitivity simulation examines the combined effect of the biogenic $(+35 \%$ BIOG) and anthropogenic $(-35 \%$ ANTH) perturbations (COMBO). For all scenarios, the acetone sources outside North America are unchanged.

Figure 7 shows the August changes to atmospheric acetone and PAN in the mid-troposphere and at the surface resulting from these source perturbations. For the $-35 \%$ ANTH scenario, atmospheric acetone decreases by up to $9 \%$ at $700 \mathrm{hPa}$ and $20 \%$ at the surface. This leads to a modest shift in the partitioning of reactive nitrogen, with PAN decreasing by up to $4 \%$. On the other hand, the increased biogenic source in the $+35 \%$ BIOG scenario leads to an atmospheric acetone increase of up to $16 \%$ at $700 \mathrm{hPa}$ and $30 \%$ at the surface, along with a PAN increase of up to $7 \%$. For the COMBO scenario, the biogenic flux increase thus more than offsets the $35 \%$ decrease to the anthropogenic source. The net effect during August is a widespread acetone increase in surface air and at $700 \mathrm{hPa}$ (up to $29 \%$ and $11 \%$, respectively) over North America (Fig. 7), with a small net PAN increase of up to $3 \%$.

The top and middle panels of Fig. 8 show the seasonality of these simulated changes in acetone and PAN mixing ratios at $700 \mathrm{hPa}$ over North America. For the COMBO scenario, we see acetone and PAN increases from May through 
October, and decreases during the colder months. The largest net change occurring during summer is relatively small (a few pptv), but positive. Any future decrease in anthropogenic acetone emissions is thus likely to be significantly offset by increased biogenic acetone emissions due to surface warming. Such warming would also affect other parameters, such as the PAN lifetime: these perturbation analyses thus represent the partial derivatives of atmospheric acetone and PAN with respect to biogenic and anthropogenic acetone source changes within North America.

Finally, we derive the PAN fraction at $700 \mathrm{hPa}$ over North America resulting from domestic acetone sources (bottom panel in Fig. 8), based on the scaled response to the perturbations above. During summer, North American acetone sources contribute only up to $6 \%$ of the total PAN abundance at $700 \mathrm{hPa}$ formed over this region (biogenic: $4 \%$; anthropogenic: $2 \%$ ). During winter, North American acetone sources (mainly anthropogenic) account for less than $2 \%$ of the PAN abundance in this part of the free troposphere.

\section{Conclusions}

We developed new constraints on natural and anthropogenic acetone sources over North America based on inverse modeling of a full year (January 2010-February 2011) of continuous atmospheric acetone measurements from the University of Minnesota tall tower Trace Gas Observatory (KCMP tall tower). We then used this information to evaluate the sensitivity of atmospheric acetone and peroxyacetyl nitrate (PAN) with respect to changes in North American biogenic and anthropogenic acetone sources.

Acetone mixing ratios measured at the KCMP tall tower ranged from $0.1 \mathrm{ppbv}$ to $4.1 \mathrm{ppbv}$, with an annual mean of $1.2 \mathrm{ppbv}$ (median 1.0 ppbv); mixing ratios were in general lower during winter, and higher in summer. Atmospheric acetone at the KCMP tall tower is well correlated with methanol ( $R=0.83$ for the full year, $n=6637$ ), consistent with observations elsewhere (Goldan et al., 1995; Riemer et al., 1998; Salisbury et al., 2003; Singh et al., 2004; Schade and Goldstein, 2006). However, due to the different mechanisms driving plant emissions of these two compounds, the seasonal peak for acetone occurs roughly one month later than that for methanol (mid-August versus mid-July). This degrades the correlation between the two compounds during summer. We found the acetone : methanol slope to be relatively consistent through all seasons (between 0.20 and 0.31 ) at the tall tower, implying similar acetone : methanol ratios for both biogenic and anthropogenic sources.

We applied the KCMP tall tower observations in a Bayesian optimization approach to develop new top-down acetone source estimates for North America. We found that the a priori model (GEOS-Chem, driven by the MEGANv2.1 biogenic inventory) underestimates acetone emissions from broadleaf trees + shrubs + herbaceous plants by $37 \%$, while

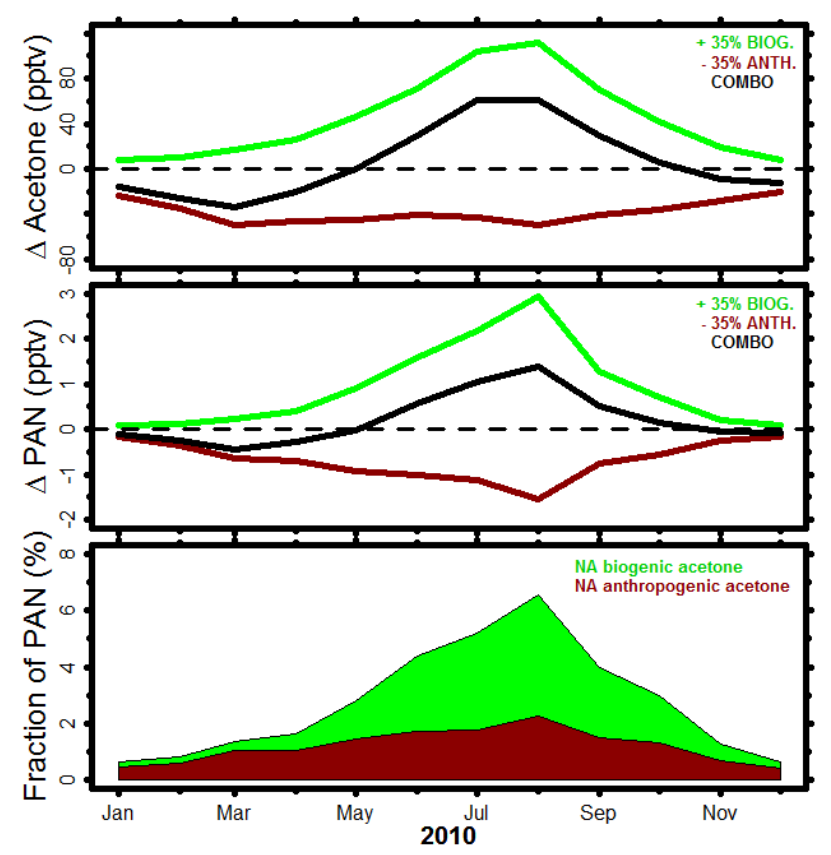

Fig. 8. Simulated change (pptv) in seasonal acetone (top panel) and PAN (middle panel) mixing ratios at $700 \mathrm{hPa}$ for the sensitivity runs shown in Fig. 7. The bottom panel shows the fractional contribution of biogenic and anthropogenic acetone sources in North America to the simulated PAN abundance. Values shown represent an average over continental North America.

overestimating needleleaf tree emissions + secondary production from biogenic precursors by $40 \%$. The overall result is a small $(16 \%)$ model underestimate of the total primary + secondary biogenic acetone source over North America. Estimated North American primary + secondary anthropogenic acetone sources, computed in the model based on EPA's NEI 2005 inventory, are accurate to within approximately $20 \%$. An optimized GEOS-Chem simulation incorporating the above findings captured $70 \%$ of the variance $(R=0.83)$ in the hourly measurements at the KCMP tall tower over the full year. The resulting North American acetone source is $10.9 \mathrm{Tg} \mathrm{a}^{-1}$, with roughly equal contributions from anthropogenic and biogenic sources. The acetone source alone is then comparable to $(\sim 75 \%)$ the total direct VOC source from North American fossil fuel combustion.

We find during winter that acetone in the US Upper Midwest arises mainly from sources outside North America $(50 \%)$, with primary $(15 \%)$ and secondary $(29 \%)$ anthropogenic sources within North America also important. During summer, North American biogenic sources predominate ( $47 \%$ primary; $14 \%$ secondary), with anthropogenic sources $(20 \%)$ and long-range transport (19\%) playing more modest roles. On a yearly basis, domestic biogenic, domestic anthropogenic and transported acetone sources are of similar importance, but with differing seasonality. 
We then applied our optimized source estimates to gauge the sensitivity of the atmospheric acetone and PAN abundance over North America to shifts in biogenic and anthropogenic acetone sources. A $35 \%$ increase to modeled primary + secondary biogenic acetone sources over North America (which is a conservative estimate of the warmingdriven emission enhancement to be expected over the 21th century) increases model acetone and PAN mixing ratios by up to $29 \%$ and $7 \%$, respectively. This increase would more than offset a comparable relative decrease $(-35 \%)$ in the anthropogenic acetone source due to future emission controls.

Acknowledgements. This work was supported by the National Science Foundation (Grant \#0937004), by the National Aeronautics and Space Administration (Grant \#NNX10AG65G), and by the Minnesota Supercomputing Institute. We thank The Current from Minnesota Public Radio (KCMP 89.3FM), along with Michael Mohr and the UMN biometeorology group for their help with the field campaign. We also thank Joost de Gouw, Carsten Warneke, Alex Guenther, and Munkhbayar Baasandorj for their generous input.

Edited by: R. McLaren

\section{References}

Aiello, M. and McLaren, R.: Measurement of airborne carbonyls using an automated sampling and analysis system, Environ. Sci. Technol., 43, 8901-8907, doi:10.1021/es901892f, 2009.

Alvarado, A., Tuazon, E. C., Aschmann, S., Arey, J., and Atkinson, R.: Products and mechanisms of the gas-phase reactions of $\mathrm{OH}$ radicals and $\mathrm{O}_{3}$ with 2-methyl-3-buten-2-ol, Atmos. Environ., 33, 2893-2905, 1999.

Andreae, M. O. and Merlet, P.: Emission of trace gases and aerosols from biomass burning, Global Biogeochem. Cy., 15, 955-966, doi:10.1029/2000GB001382, 2001.

Arnold, F., Bürger, V., Droste-Fanke, B., Grimm, F., Krieger, A., Schneider, J., and Stilp, T.: Acetone in the upper troposphere and lower stratosphere: Impact on trace gases and aerosols, Geophys. Res. Lett., 24, 3017-3020, 1997.

Arnold, S. R., Chipperfield, M. P., and Blitz, M. A.: A threedimensional model study of the effect of new temperaturedependent quantum yields for acetone photolysis, J. Geophys. Res., 110, D22305, doi:10.1029/2005JD005998, 2005.

Baker, B., Guenther, A., Greenberg, J., and Fall, R.: Canopy level fluxes of 2-methyl-3-buten-2-ol, acetone, and methanol by a portable relaxed eddy accumulation system, Environ. Sci. Technol., 35, 1701-1708, doi:10.1021/es001007j, 2001.

Bey, I., Jacob, D. J., Yantosca, R. M., Logan, J. A., Field, B. D., Fiore, A. M., Li, Q., Liu, H. Y., Mickley, L. J., and Schultz, M. G.: Global modeling of tropospheric chemistry with assimilated meteorology: Model description and evaluation, J. Geophys. Res., 106, 23073-23095, doi:10.1029/2001JD000807, 2001.

Blitz, M. A., Heard, D. E., Pilling, M. J., Arnold, S. R., and Chipperfield, M. P.: Pressure and temperature-dependent quantum yields for the photodissociation of acetone between 279 and $327.5 \mathrm{~nm}$,
Geophys. Res. Lett., 31, L06111, doi:10.1029/2003GL018793, 2004.

Chatfield, R. B., Gardner, E. P., and Calvert, J. G.: Sources and sinks of acetone in the troposphere: Behavior of reactive hydrocarbons and a stable product, J. Geophys. Res., 92, 4208-4216, 1987.

Chen, D., Wang, Y., McElroy, M. B., He, K., Yantosca, R. M., and Le Sager, P.: Regional CO pollution and export in China simulated by the high-resolution nested-grid GEOS-Chem model, Atmos. Chem. Phys., 9, 3825-3839, doi:10.5194/acp-9-3825-2009, 2009.

de Gouw, J. A. and Warneke, C.: Measurements of volatile organic compounds in the earth's atmosphere using proton-transferreaction mass spectrometry, Mass Spectrom. Rev., 26, 223-257, doi:10.1002/mas.20119, 2007.

de Gouw, J. A., Howard, C. J., Custer, T. G., and Fall, R.: Emissions of volatile organic compounds from cut grass and clover are enhanced during the drying process, Geophys. Res. Lett., 26, 811-814, 1999.

de Gouw, J. A., Goldan, P. D., Warneke, C., Kuster, W. C., Roberts, J. M., Marchewka, M., Bertman, S. B., Pszenny, A. A. P., and Keene, W. C.: Validation of proton transfer reaction-mass spectrometry (PTR-MS) measurements of gas-phase organic compounds in the atmosphere during the New England Air Quality Study (NEAQS) in 2002, J. Geophys. Res., 108, 4682, doi:10.1029/2003jd003863, 2003.

de Gouw, J. A., Middlebrook, A. M., Warneke, C., Goldan, P. D., Kuster, W.C., Roberts, J. M., Fehsenfeld, F. C., Worsnop, D. R., Canagaratna, M. R., Pszenny, A. A. P., Keene, W. C., Marchewka, M., Bertman, S. B., and Bates, T. S.: Budget of organic carbon in a polluted atmosphere: Results from the New England Air Quality Study in 2002, J. Geophys. Res., 110, D16305, doi:10.1029/2004jd005623, 2005.

de Reus, M., Fischer, H., Arnold, F., de Gouw, J., Holzinger, R., Warneke, C, and Williams, J.: On the relationship between acetone and carbon monoxide in different air masses, Atmos. Chem. Phys., 3, 1709-1723, doi:10.5194/acp-3-1709-2003, 2003.

Elias, T., Szopa, S., Zahn, A., Schuck, T., Brenninkmeijer, C., Sprung, D., and Slemr, F.: Acetone variability in the upper troposphere: analysis of CARIBIC observations and LMDz-INCA chemistry-climate model simulations, Atmos. Chem. Phys., 11, 8053-8074, doi:10.5194/acp-11-8053-2011, 2011.

Environmental Protection Agency National Emission Inventory for 2005: http://www.epa.gov/ttnchie1/net/2005inventory.html, last access: 1 December 2011.

Fall, R.: Abundant oxygenates in the atmosphere: A biochemical perspective, Chem. Rev., 103, 4941-4951, doi:10.1021/cr0206521, 2003.

Fall, R. and Benson, A. A.: Leaf methanol - the simplest natural product from plants, Trends Plant Sci., 1, 296-301, doi:10.1016/S1360-1385(96)88175-0, 1996.

Fischer, E. V., Jacob, D. J., Millet, D. B., Yantosca, R. M., and Mao, J.: The role of the ocean in the global atmospheric budget of acetone, Geophys. Res. Lett., 39, L01807, doi:10.1029/2011GL050086, 2012.

Folberth, G. A., Hauglustaine, D. A., Lathière, J., and Brocheton, F.: Interactive chemistry in the Laboratoire de Météorologie Dynamique general circulation model: model description and impact analysis of biogenic hydrocarbons on tropospheric chemistry, Atmos. Chem. Phys., 6, 2273-2319, doi:10.5194/acp-6- 
2273-2006, 2006.

Folkins, I. and Chatfield, R.: Impact of acetone on ozone production and $\mathrm{OH}$ in the upper troposphere at high $\mathrm{NO}_{\mathrm{x}}$, J. Geophys. Res., 105, 11585-11600, 2000.

Gierczak, T., Burkholder, J. B., Bauerle, S., and Ravishankara, A. R.: Photochemistry of acetone under tropospheric conditions, Chem. Phys., 231, 229-244, 1998.

Goldan, P. D., Kuster, W. C., Fehsenfeld, F. C., and Montzka, S. A.: Hydrocarbon measurements in the southeastern United States: The Rural Oxidants in the Southern Environment (ROSE) program 1990, J. Geophys. Res., 100, 25945-25963, 1995.

Goldstein, A. H. and Schade, G. W.: Quantifying biogenic and anthropogenic contributions to acetone mixing ratios in a rural environment, Atmos. Environ., 34, 4997-5006, 2000.

Griffis, T. J., Baker, J. M., Sargent, S. D., Eriksson, M., Corcoran, J., Chen, M., and Billmark, K.: Influence of $\mathrm{C}_{4}$ vegetation on ${ }^{13} \mathrm{CO}_{2}$ discrimination and isoforcing in the Upper Midwest, United States, Global Biogeochem. Cy., 24, GB4006, doi:10.1029/2009GB003768, 2010.

Guenther, A. B., Jiang, X., Heald, C. L., Sakulyanontvittaya, T., Duhl, T., Emmons, L. K., and Wang, X.: The Model of Emissions of Gases and Aerosols from Nature version 2.1 (MEGAN2.1): an extended and updated framework for modeling biogenic emissions, Geosci. Model Dev., 5, 1471-1492, doi:10.5194/gmd-51471-2012, 2012.

Guo, H., Ling, Z. H., Cheung, K., Wang, D. W., Simpson, I. J., and Blake, D. R.: Acetone in the atmosphere of Hong Kong: Abundance, sources and photochemical precursors, Atmos. Environ., 65, 80-88, doi:10.1016/j.atmosenv.2012.10.027, 2013.

Heald, C. L., Jacob, D. J., Jones, D. B. A., Palmer, P. I., Logan, J. A., Streets, D. G., Sachse, G. W., Gille, J. C., Hoffman, R. N., and Nehrkorn, T.: Comparative inverse analysis of satellite (MOPITT) and aircraft (TRACE-P) observations to estimate Asian sources of carbon monoxide, J. Geophys. Res., 109, D23306, doi:10.1029/2004JD005185, 2004.

Helmig, D., Bocquet, F., Pollmann, J., and Revermann, T.: Analytical techniques for sesquiterpene emission rate studies in vegetation enclosure experiments, Atmos. Environ., 38, 557-572, doi:10.1016/j.atmosenv.2003.10.012, 2004

Hu, L., Millet, D. B., Mohr, M. J., Wells, K. C., Griffis, T. J., and Helmig, D.: Sources and seasonality of atmospheric methanol based on tall tower measurements in the US Upper Midwest, Atmos. Chem. Phys., 11, 11145-11156, doi:10.5194/acp-1111145-2011, 2011.

Jacob, D. J., Field, B. D., Jin, E. M., Bey, I., Li, Q. B., Logan, J. A., Yantosca, R. M., and Singh, H. B.: Atmospheric budget of acetone, J. Geophys. Res., 107, 4100, doi:10.1029/2001JD000694, 2002.

Jacob, D. J., Field, B. D., Li, Q. B., Blake, D. R., de Gouw, J., Warneke, C., Hansel, A., Wisthaler, A., Singh, H. B., and Guenther, A.: Global budget of methanol: Constraints from atmospheric observations, J. Geophys. Res., 110, D08303, doi:10.1029/2004JD005172, 2005.

Jaeglé, L., Jacob, D. J., Wennberg, P. O., Spivakovsky, C. M., Hanisco, T. F., Lanzendorf, E. J., Hintsa, E. J., Fahey, D. W., Keim, E. R., Proffitt, M. H., Atlas, E. L., Flocke, F., Schauffler, S., McElroy, C. T., Midwinter, C., Pfister, L., and Wilson, J. C.: Observed $\mathrm{OH}$ and $\mathrm{HO}_{2}$ in the upper troposphere suggest a major source from convective injection of peroxides, Geophys. Res.
Lett., 24, 3181-3184, 1997.

Jaeglé, L., Jacob, D. J., Brune, W. H., and Wennberg, P. O.: Chemistry of $\mathrm{HO}_{\mathrm{x}}$ radicals in the upper troposphere, Atmos. Environ., 35, 469-489, doi:10.1016/S1352-2310(00)00376-9, 2001.

Janson, R., De Serves, C., and Romero, R.: Emission of isoprene and carbonyl compounds from a boreal forest and wetland in Sweden, Agr. Forest Meteorol., 98, 671-681, 1999.

Jardine, K. J., Sommer, E. D., Saleska, S. R., Huxman, T. E., Harley, P. C., and Abrell, L.: Gas phase measurements of pyruvic acid and its volatile metabolites, Environ. Sci. Technol., 44, 24542460, doi:10.1021/es903544p, 2010.

Karl, T., Guenther, A., Spirig, C., Hansel, A., and Fall, R.: Seasonal variation of biogenic VOC emissions above a mixed hardwood forest in northern Michigan, Geophys. Res. Lett., 30, 2186, doi:10.1029/2003g1018432, 2003.

Karl, T., Potosnak, M., Guenther, A., Clark, D., Walker, J., Herrick, J.D., and Geron, C.: Exchange processes of volatile organic compounds above a tropical rain forest: Implications for modeling tropospheric chemistry above dense vegetation, J. Geophys. Res, 109, D18306, doi:10.1029/2004JD004738, 2004.

Karl, T. G., Spirig, C., Rinne, J., Stroud, C., Prevost, P., Greenberg, J., Fall, R., and Guenther, A.: Virtual disjunct eddy covariance measurements of organic compound fluxes from a subalpine forest using proton transfer reaction mass spectrometry, Atmos. Chem. Phys., 2, 279-291, doi:10.5194/acp-2-279-2002, 2002.

Lathière, J., Hauglustaine, D. A., Friend, A. D., De NobletDucoudré, N., Viovy, N., and Folberth, G. A.: Impact of climate variability and land use changes on global biogenic volatile organic compound emissions, Atmos. Chem. Phys., 6, 2129-2146, doi:10.5194/acp-6-2129-2006, 2006.

Lewis, A. C., Hopkins, J. R., Carpenter, L. J., Stanton, J., Read, K. A., and Pilling, M. J.: Sources and sinks of acetone, methanol, and acetaldehyde in North Atlantic marine air, Atmos. Chem. Phys., 5, 1963-1974, doi:10.5194/acp-5-1963-2005, 2005.

Lin, J. T. and McElroy, M. B.: Impacts of boundary layer mixing on pollutant vertical profiles in the lower troposphere: Implications to satellite remote sensing, Atmos. Environ., 44, 17261739, doi:10.1016/j.atmosenv.2010.02.009, 2010.

MacDonald, R. C. and Fall, R.: Detection of substantial emissions of methanol from plants to the atmosphere, Atmos. Environ. A. Gen., 27, 1709-1713, doi:10.1016/0960-1686(93)90233-O, 1993a.

MacDonald, R. C. and Fall, R.: Acetone emission from conifer buds, Phytochemistry, 34, 991-994, 1993b.

Mao, J., Jacob, D. J., Evans, M. J., Olson, J. R., Ren, X., Brune, W. H., Clair, J. M. S., Crounse, J. D., Spencer, K. M., Beaver, M. R., Wennberg, P. O., Cubison, M. J., Jimenez, J. L., Fried, A., Weibring, P., Walega, J. G., Hall, S. R., Weinheimer, A. J., Cohen, R. C., Chen, G., Crawford, J. H., McNaughton, C., Clarke, A. D., Jaeglé, L., Fisher, J. A., Yantosca, R. M., Le Sager, P., and Carouge, C.: Chemistry of hydrogen oxide radicals $\left(\mathrm{HO}_{\mathrm{x}}\right)$ in the Arctic troposphere in spring, Atmos. Chem. Phys., 10, 58235838, doi:10.5194/acp-10-5823-2010, 2010.

Marandino, C., De Bruyn, W., Miller, S., Prather, M., and Saltzman, E.: Oceanic uptake and the global atmospheric acetone budget, Geophys. Res. Lett, 32, L15806, doi:10.1029/2005GL023285, 2005.

Martin, R. V., Jacob, D. J., Yantosca, R. M., Chin, M., and Ginoux, P.: Global and regional decreases in tropospheric oxidants from 
photochemical effects of aerosols, J. Geophys. Res., 108, 4097, doi:10.1029/2002JD002622, 2003.

McKeen, S., Gierczak, T., Burkholder, J., Wennberg, P., Hanisco, T., Keim, E., Gao, R.S., Liu, S., Ravishankara, A., and Fahey, D.: The photochemistry of acetone in the upper troposphere: A source of odd-hydrogen radicals, Geophys. Res. Lett., 24, $3177-$ 3180, 1997.

Millet, D. B., Jacob, D. J., Custer, T. G., de Gouw, J. A., Goldstein, A. H., Karl, T., Singh, H. B., Sive, B. C., Talbot, R. W., Warneke, C., and Williams, J.: New constraints on terrestrial and oceanic sources of atmospheric methanol, Atmos. Chem. Phys., 8, 68876905, doi:10.5194/acp-8-6887-2008, 2008.

Palmer, P. I., Jacob, D. J., Jones, D. B. A., Heald, C. L., Yantosca, R. M., Logan, J. A., Sachse, G. W., and Streets, D. G.: Inverting for emissions of carbon monoxide from Asia using aircraft observations over the western Pacific, J. Geophys. Res., 108, 8828, doi:10.1029/2003JD003397, 2003.

Pollmann, J., Ortega, J., and Helmig, D.: Analysis of atmospheric sesquiterpenes: Sampling losses and mitigation of ozone interferences, Environ. Sci. Technol., 39, 9620-9629, doi:10.1021/es050440w, 2005.

Potter, C., Klooster, S., Bubenheim, D., Singh, H. B., and Myneni, R.: Modeling terrestrial biogenic sources of oxygenated organic emissions, Earth Interact., 7, 1-15, 2003.

Read, K. A., Carpenter, L. J., Arnold, S. R., Beale, R., Nightingale, P. D., Hopkins, J. R., Lewis, A. C., Lee, J. D., Mendes, L., and Pickering, S. J.: Multiannual observations of acetone, methanol, and acetaldehyde in remote tropical Atlantic air: Implications for atmospheric OVOC budgets and oxidative capacity, Environ. Sci. Technol., 46, 11028-11039, doi:10.1021/es302082p, 2012.

Reissell, A., Harry, C., Aschmann, S. M., Atkinson, R., and Arey, J.: Formation of acetone from the $\mathrm{OH}$ radical- and $\mathrm{O}_{3}$-initiated reactions of a series of monoterpenes, J. Geophys. Res., 104, 1386913879, 1999.

Riemer, D., Pos, W., Milne, P., Farmer, C., Zika, R., Apel, E., Olszyna, K., Kliendienst, T., Lonneman, W., Bertman, S., Shepson, P., and Starn, T.: Observations of nonmethane hydrocarbons and oxygenated volatile organic compounds at a rural site in the southeastern United States, J. Geophys. Res., 103, 28111-28128, 1998.

Rodgers, C. D.: Inverse methods for atmospheric sounding: Theory and practice, World Sci., Singapore, 2000.

Salisbury, G., Williams, J., Holzinger, R., Gros, V., Mihalopoulos, N., Vrekoussis, M., Sarda-Estève, R., Berresheim, H., von Kuhlmann, R., Lawrence, M., and Lelieveld, J.: Ground-based PTR-MS measurements of reactive organic compounds during the MINOS campaign in Crete, July-August 2001, Atmos. Chem. Phys., 3, 925-940, doi:10.5194/acp-3-925-2003, 2003.

Sander, S. P., Golden, D., Kurylo, M., Moortgat, G., Wine, P., Ravishankara, A., Kolb, C., Molina, M., Finlayson-Pitts, B., and Huie, R.: Chemical kinetics and photochemical data for use in atmospheric studies, JPL Publ., 06-2, 684, 2011.

Schade, G. W. and Goldstein, A. H.: Fluxes of oxygenated volatile organic compounds from a ponderosa pine plantation, J. Geophys. Res., 106, 3111-3123, doi:10.1029/2000JD900592, 2001.

Schade, G. W. and Goldstein, A. H.: Seasonal measurements of acetone and methanol: Abundances and implications for atmospheric budgets, Global Biogeochem. Cy., 20, GB1011, doi:10.1029/2005gb002566, 2006.
Simpson, I. J., Akagi, S. K., Barletta, B., Blake, N. J., Choi, Y., Diskin, G. S., Fried, A., Fuelberg, H. E., Meinardi, S., Rowland, F. S., Vay, S. A., Weinheimer, A. J., Wennberg, P. O., Wiebring, P., Wisthaler, A., Yang, M., Yokelson, R. J., and Blake, D. R.: Boreal forest fire emissions in fresh Canadian smoke plumes: C1-C10 volatile organic compounds (VOCs), $\mathrm{CO}_{2}, \mathrm{CO}, \mathrm{NO}_{2}$, $\mathrm{NO}, \mathrm{HCN}$ and $\mathrm{CH}_{3} \mathrm{CN}$, Atmos. Chem. Phys., 11, 6445-6463, doi:10.5194/acp-11-6445-2011, 2011.

Singh, H., O'Hara, D., Herlth, D., Sachse, W., Blake, D., Bradshaw, J., Kanakidou, M., and Crutzen, P.: Acetone in the atmosphere: Distribution, sources, and sinks, J. Geophys. Res., 99, 1805-1819, 1994.

Singh, H. B. and Hanst, P. L.: Peroxyacetyl nitrate (PAN) in the unpolluted atmosphere: An important reservoir for nitrogen oxides, Geophys. Res. Lett., 8, 941-944, 1981.

Singh, H. B., Kanakidou, M., Crutzen, P. J., and Jacob, D. J.: High mixing ratios and photochemical fate of oxygenated hydrocarbons in the global troposphere, Nature, 378, 50-54, doi:10.1038/378050a0, 1995.

Singh, H. B., Chen, Y., Tabazadeh, A., Fukui, Y., Bey, I., Yantosca, R., Jacob, D., Arnold, F., Wohlfrom, K., Atlas, E., Flocke, F., Blake, D., Blake, N., Heikes, B., Snow, J., Talbot, R., Gregory, G., Sachse, G., Vay, S., and Kondo, Y.: Distribution and fate of selected oxygenated organic species in the troposphere and lower stratosphere over the Atlantic, J. Geophys. Res., 105, 3795-3805, doi:10.1029/1999JD900779, 2000.

Singh, H. B., Salas, L. J., Chatfield, R. B., Czech, E., Fried, A., Walega, J., Evans, M. J., Field, B. D., Jacob, D. J., Blake, D., Heikes, B., Talbot, R., Sachse, G., Crawford, J. H., Avery, M. A., Sandholm, S., and Fuelberg, H.: Analysis of the atmospheric distribution, sources, and sinks of oxygenated volatile organic chemicals based on measurements over the Pacific during TRACE-P, J. Geophys. Res., 109, D15S07, doi:10.1029/2003jd003883, 2004.

Sinha, V., Williams, J., Meyerhöfer, M., Riebesell, U., Paulino, A. I., and Larsen, A.: Air-sea fluxes of methanol, acetone, acetaldehyde, isoprene and DMS from a Norwegian fjord following a phytoplankton bloom in a mesocosm experiment, Atmos. Chem. Phys., 7, 739-755, doi:10.5194/acp-7-739-2007, 2007.

Sjostedt, S. J., Leaitch, W. R., Levasseur, M., Scarratt, M., Michaud, S., Motard-Côté, J., Burkhart, J. H., and Abbatt, J. P. D.: Evidence for the uptake of atmospheric acetone and methanol by the Arctic Ocean during late summer DMS-Emission plumes, J. Geophys. Res., 117, D12303, doi:10.1029/2011JD017086, 2012.

Taddei, S., Toscano, P., Gioli, B., Matese, A., Miglietta, F., Vaccari, F. P., Zaldei, A., Custer, T., and Williams, J.: Carbon dioxide and acetone air-sea fluxes over the southern Atlantic, Environ. Sci. Technol., 43, 5218-5222, doi:10.1021/es8032617, 2009.

van der Werf, G. R., Randerson, J. T., Giglio, L., Collatz, G. J., Mu, M., Kasibhatla, P. S., Morton, D. C., DeFries, R. S., Jin, Y., and van Leeuwen, T. T.: Global fire emissions and the contribution of deforestation, savanna, forest, agricultural, and peat fires (19972009), Atmos. Chem. Phys., 10, 11707-11735, doi:10.5194/acp10-11707-2010, 2010.

van Donkelaar, A., Martin, R. V., Pasch, A. N., Szykman, J. J., Zhang, L., Wang, Y. X., and Chen, D.: Improving the accuracy of daily satellite-derived ground-level fine aerosol concentration estimates for North America, Environ. Sci. Technol., 46, 1197111978, doi:10.1021/es3025319, 2012. 
Wang, Y. X., McElroy, M. B., Jacob, D. J., and Yantosca, R. M.: A nested grid formulation for chemical transport over Asia: Applications to CO, J. Geophys. Res., 109, D22307, doi:10.1029/2004JD005237, 2004.

Warneke, C., Karl, T., Judmaier, H., Hansel, A., Jordan, A., Lindinger, W., and Crutzen, P. J.: Acetone, methanol, and other partially oxidized volatile organic emissions from dead plant matter by abiological processes: Significance for atmospheric $\mathrm{HO}_{\mathrm{x}}$ chemistry, Global Biogeochem. Cy., 13, 9-17, doi:10.1029/98GB02428, 1999.

Wells, K. C., Millet, D. B., Hu, L., Cady-Pereira, K. E., Xiao, Y., Shephard, M. W., Clerbaux, C. L., Clarisse, L., Coheur, P.F., Apel, E. C., de Gouw, J., Warneke, C., Singh, H. B., Goldstein, A. H., and Sive, B. C.: Tropospheric methanol observations from space: retrieval evaluation and constraints on the seasonality of biogenic emissions, Atmos. Chem. Phys., 12, 5897-5912, doi:10.5194/acp-12-5897-2012, 2012.
Wennberg, P., Hanisco, T., Jaeglé, L., Jacob, D., Hintsa, E., Lanzendorf, E., Anderson, J., Gao, R. S., Keim, E., and Donnelly, S.: Hydrogen radicals, nitrogen radicals, and the production of $\mathrm{O}_{3}$ in the upper troposphere, Science, 279, 49-53, 1998.

Williams, J., Holzinger, R., Gros, V., Xu, X., Atlas, E., and Wallace, D. W. R.: Measurements of organic species in air and seawater from the tropical Atlantic, Geophys. Res. Lett., 31, L23S06, doi:10.1029/2004g1020012, 2004.

Zhang, L., Jacob, D. J., Smith-Downey, N. V., Wood, D. A., Blewitt, D., Carouge, C. C., van Donkelaar, A., Jones, D. B. A., Murray, L. T., and Wang, Y.: Improved estimate of the policy-relevant background ozone in the United States using the GEOS-Chem global model with $1 / 2^{\circ} \times 2 / 3^{\circ}$ horizontal resolution over North America, Atmos. Environ., 45, 6769-6776, doi:10.1016/j.atmosenv.2011.07.054, 2011. 